\title{
Relating costs to the user value of farmland biodiversity measurements
}

\author{
S. Targetti ${ }^{\text {a, b, }{ }^{*}, \text { F. Herzog }}{ }^{\text {}}$, I.R. Geijzendorffer ${ }^{\text {d }}$, P. Pointereau ${ }^{\text {e }}$, D. Viaggi ${ }^{b}$ \\ a Institute of Advanced Studies, Aix-Marseille University, 13004 Marseille, France \\ b Department of Agricultural Sciences, University of Bologna, 40127 Bologna, Italy \\ ${ }^{c}$ Agroscope, Institute for Sustainability Sciences, CH-8046 Zurich, Switzerland \\ d Institut Méditerranéen de Biodiversité et d'Ecologie marine et continentale, Aix Marseille Université, CNRS, IRD, Avignon Université, Technopôle Arbois- \\ Méditerranée, Bât. Villemin - BP 80, F-13545 Aix-en-Provence Cedex 04, France \\ e SOLAGRO, Initiatives and Innovation for Energy, Agriculture, and Environment, 31076 Toulouse, France
}

\section{A R T I C L E I N F O}

Article history:

Received 26 March 2015

Accepted 28 August 2015

Keywords:

Agriculture

Farmer

Volunteer

Citizen science

Biodiversity indicators

Multi-criteria evaluation

Stakeholders

\begin{abstract}
A B S T R A C T
The impact of agricultural management on global biodiversity highlights the need for farm-scale monitoring programmes capable of determining the performance of agriculture practices. Yet the identification of appropriate indicators is a challenging process and one that involves considering a number of different aspects and requirements. Besides the attention given to scientific effectiveness, relevant but less studied issues related to biodiversity measurements include the economic feasibility of monitoring programmes and the relevance of indicators for different end-users. In this paper, we combine an analytic assessment of costs and a stakeholder-based evaluation of the usefulness of a set of biodiversity-related parameters (habitat mapping, vegetation, bees, earthworms, spiders, and a farmer questionnaire) tested for scientific consistency in 12 European case studies and on more than 14,000 ha of farmland. The results point to the possibility of meeting the expectations of different end-users (administrators, farmers and consumers) with a common indicator set. Combining costs and usefulness also suggests the possibility of designing more efficient monitoring approaches involving private agencies and networks of volunteers and farmers for the field data collection at different stages of a monitoring programme. Although complex, such an approach would make it possible to enhance the effectiveness of available funds for farmland biodiversity monitoring.
\end{abstract}

\section{Introduction}

Biodiversity is rapidly decreasing and there is a general consensus that this process will raise severe concerns for future human well-being (Balvanera et al., 2006; Bommarco et al., 2013; Brooks et al., 2014). Despite global and national political initiatives and public spending on conservation (Hanley et al., 2012), data gaps hinder the consistent monitoring and interpretation of the trends in biodiversity change (Tittensor et al., 2014; Walpole et al., 2009). This has resulted in the creation of multiple initiatives aimed at developing frameworks for monitoring and analysis (e.g. the Essential Biodiversity Variables; cf. Pereira et al., 2013) and initiatives for the mobilisation of data (Hoffmann et al., 2014).

\footnotetext{
* Corresponding author. Institute of Advanced Studies, Aix-Marseille University, 13004 Marseille, France.

E-mail address: targettis@gmail.com (S. Targetti).
}

These are robust data-driven scientific approaches; however, this does not necessarily mean that those who will use this information feel that these indicators convey the most important information in an understandable way (Bell and Morse, 2013).

The potential (positive/negative) impacts of agricultural systems on global biodiversity are widely acknowledged (Tilman et al., 2001; Kleijn et al., 2009). The political commitment towards farmland biodiversity and related ecosystems is also demonstrated in the EU Common Agricultural Policy (CAP, Reg. EU 1305, 1306 and 1307/2013). For instance, Pe'er et al. (2014) estimated that $30 \%$ of the CAP budget is devoted to environmental targets, including biodiversity (accounting for around $€ 122$ billion earmarked in the current programming period, 2014-2020). Despite various controversial outcomes arising from agro-environmental policies targeting farmland biodiversity (Kleijn et al., 2011; Pe'er et al., 2014) point to the need for improved monitoring programmes (EC, 2011), and the economic benefits that can be expected from biodiversity 
monitoring have been asserted by a number of authors (Balmford and Gaston, 1999; James et al., 1999; White and Sadler, 2012; Armsworth et al., 2012), no budget is currently earmarked for the direct monitoring of the CAP impact on biodiversity. The minor efforts included in the monitoring and evaluation systems of the Rural Development Programmes (RDP) in the context of High Nature Value (HNV) farmland constitute an exception, yet such efforts rely on land use information rather than direct biodiversity indicators (Beaufoy and Cooper, 2009).

Budget constraints are considered one of the major current limitations to biodiversity monitoring activities (Danielsen et al., 2005; McDonald-Madden et al., 2011; but see also Geijzendorffer et al., in press). In this context, raising the awareness of stakeholders can greatly support the implementation of monitoring schemes (Bell et al., 2012) while their direct involvement in monitoring implementation can allow for noteworthy budget savings (Levrel et al., 2010; Targetti et al., 2014; Theobald et al., 2015). Therefore, cost efficiency and stakeholder relevance should be considered in the development of a biodiversity indicator set (Noss, 1990; Rempel et al., 2004; Bockstaller et al., 2009). However, the identification of an indicator set able to strike a balance between the requirements and expectations of different stakeholder groups is a challenge that entails an assessment of what can be realistically measured to address different objectives in different contexts (Dudley et al., 2005).

The literature defines four key aspects for the selection of biodiversity indicators: scientific consistency, practicability, feasibility, and usefulness. Scientific consistency of indicators means that the indicators provide a reliable estimation of biodiversity, that they are independent from expert judgment, based on objective methods, and can be repeated independently of the observer (Favreau et al., 2006; Rodrigues and Brooks, 2007). Practicability and feasibility concern the operational requirements of indicator measurements in terms of effort and budget limitations (Caughlan and Oakley, 2001; Hagan and Whitman, 2006). Usefulness is related to the potential of the indicators to convey information to those actors who are expected to use it (Dudley et al., 2005; Turnhout et al., 2007; Bell and Morse, 2013). Usefulness of an indicator depends on the relevance of the information conveyed and therefore depends greatly on the type of audience that is targeted (Heink and Kowarik, 2010) and its communication potential to the different end-users that may be interested in the information.

Farmland biodiversity indicators are relevant for policy makers and administrators when the information supports the decisionmaking process e.g. for an efficient design of agro-environmental measures, and for the setting up of guidelines e.g. in the context of pesticide and GMO regulation (Firbank et al., 2003; White, 2005; Zabel and Roe, 2009; Hanley et al., 2012). Also, reporting the biodiversity status of farms to farmers could lead to the integration of environmental knowledge into farmers' decision making (Luescher et al., 2014). By becoming more aware of the functioning of the ecological sub-systems in which they operate, farmers can develop the capacity to manage their ecosystem services supply and motivate the participation in conservation programmes (Page and Bellotti, 2015). Indeed, improved awareness and understanding would help farmers in the management choices between efforts for direct producer benefits (e.g. production of marketable goods) and benefits to the society (e.g. recreation or biodiversity conservation), eventually rewarded by support policies (Vanclay, 2004; Dale and Polasky, 2007; Bommarco et al., 2013). This is particularly important in the case of complementary jointness between different bundles of ecosystem services supplied by agricultural lands (Wossink and Swinton, 2007; Firbank et al., 2012). Farmers are commonly more motivated to value the flow of ecosystem services that provide direct on-farm benefits (Zhang et al., 2007), whereas consumers have also interest in ecosystem services that are manifested substantially at scales above that of the plot, field or farm (Swift et al., 2004). Therefore, the attachment of environmental added-value to specific agricultural products could potentially reward environmentally friendly practices (e.g. organic farming; Sutherland, 2011), stimulate the development of "green farm" brands and generate cooperative behaviour at the landscape level (Goldman et al., 2007; Cong et al., 2014; Zavalloni et al., 2015).

Whilst there is a large body of literature focussing on the scientific quality of biodiversity indicators (e.g. Favreau et al., 2006 for a review), a limited number of studies address the relevance of indicators for different stakeholder groups (e.g. Turnhout et al., 2007; Bell and Morse, 2013). A recent paper addressing the costs of farmland biodiversity (Targetti et al., 2014) allows for an analysis combining the costs of data collection for biodiversity indicators and the usefulness of information as perceived by different stakeholders.

In this work, we relate the cost of the measurement of farmland biodiversity to a stakeholder-based assessment of the relevance of a set of indicators. The objective of this paper is to assess the potential of a set of biodiversity indicators to respond to monitoring needs based on: a) their ability to match the expectations of different end-users (administrators, farmers, consumers); and b) their cost. This study builds upon: a) a set of biodiversity indicators tested for scientific consistency in 12 European case studies (Herzog et al., 2013), b) an evaluation of costs for measuring that set of indicators (Targetti et al., 2014), and c) the evaluation of the usefulness of these indicators for different end-users based on a set of criteria elicited by a stakeholder panel and the concept of weights rooted in Multi-Criteria Evaluation (MCE) theory.

\section{Materials and methods}

\subsection{Background: elicitation of stakeholders' values}

Following Reed (2008), stakeholders can be defined as those affecting or that can be affected by a decision. In our context, these are exponents of interest groups, NGOs, land management agencies, landowners, consumers, etc.

Stakeholder involvement in environmental management is currently increasing and promoted by local and international agencies e.g. in the so-called citizen-science approach (e.g. European Environment Agency, 2013a, 2013b). One main reason for this trend is that environmental decisions typically encompass complex, urgent, and uncertain issues involving multiple divergent interests affecting different interest groups (Gregory and Keeney, 1994; Funtowicz and Ravetz, 1994; Rutgers et al., 2012). Stakeholder involvement in the decision making process is therefore considered an affordable and appropriate means for the evaluation of different alternatives when the collection of "hard" data is hampered by budgetary and time requirements (Kuhnert et al., 2010).

Indicators including values and conveying information relevant for stakeholders are acknowledged to be an effective tool capable of enhancing the quality, durability, and sustainability of decisions and are particularly important in the decision making process concerning agro-environmental issues (Dudley et al., 2005; Reed, 2008). Indeed, the aim of indicators to transfer scientific knowledge into usable knowledge underscores the need to include stakeholder perspectives from the early phases of the selection and development of indicators, as well as the importance of preliminary assessments of the usefulness of indicators against a range of stakeholder needs and expectations (Turnhout et al., 2007). The assessment of the usefulness of an indicator can follow two main approaches: An indirect approach e.g. tracing 
back the inclusion of participatory approaches in the indicator development or assessing the actual utilization of the indicator (Bell et al., 2012); or a direct approach that evaluate the respondence of the indicators to a set of stakeholder criteria (e.g. Chess et al., 2005). The former method provides an objective evaluation of success but fails to measure the respondence of the indicators to different expectations and does not provide explicit directions for improvements to an indicator set. The second approach gives room for an analytical assessment of the indicators and allows for the measurement of the performance in relation to one or more objectives. This approach, though, involves the elicitation of stakeholder values based on a solid methodological background (Martin et al., 2011).

MCE includes a wide range of methods and procedures developed since the 1970s and designed for the formal integration of multiple conflicting criteria into the decision making process. In the beginning, MCE was aimed at supporting a decision maker in the decision making process. More recently, MCE tools have been developed specifically to include the elicitation of stakeholder values in participative approaches (e.g. Participatory MultiCriteria Evaluation; Garmendia and Gamboa, 2012; Social MultiCriteria Evaluation; Munda, 2004). In general, the aim of MCE is to model the best solution from a feasible set of possible solutions or the identification of the most important or most influential factors impacting on management decisions (Kou et al., 2011). Conceptually, the target of MCE is the maximization of the utility or value function for a decision maker, depending on a discrete set of criteria or attributes (Wallenius et al., 2008). ${ }^{1}$ A central concept of MCE is the notion of weights, a-dimensional coefficients attached to a set of $n$ criteria that characterize a specific decision alternative. Each alternative can be described by an $n$-dimensional vector $\bar{x}=\left(x_{i}, x_{j}, \ldots, x_{n}\right)$ composed of $n$ weighted criteria so that the utility (or value) function $U(\bar{x})$ can be compared to other options.

Relevant issues in MCE are the choice of the weight elicitation and aggregation procedure (Goodwin and Wright, 2009). The goal of the elicitation is to define a procedure that suits the objectives of the research and that is capable of dealing with the typical biases affecting stakeholder judgments (i.e. groupthink, overreaction, overconfidence, advocacy, anchoring, etc.; Martin et al., 2011).

Aggregation of weights consists of a procedure that synthesizes the opinions of different stakeholders. The aggregation can follow a range of methods including procedures based on behavioural aggregation to reach consensus agreements (e.g. the Delphi approach), or methods based on mathematical combinations of individual judgments (e.g. simple aggregation like arithmetic or geometric means, weighted-group means, or more complex rules such as the singular value decomposition, Gass and Rapcsak, 1998; or Bayesian-based models, e.g. Kuhnert et al., 2005). Different weighting and aggregation techniques exist but decisive solutions for the selection of the most effective practice have not yet been attained (Bartolini et al., 2011). In practice, the decision context, a clear articulation of the research structure framing the criteria at stake and the type of stakeholder knowledge available are crucial factors that can help the selection of the most appropriate elicitation process (Roy and Słowinski, 2013). Attentive design of the elicitation process can lead, at the very least, to a level of rigour comparable to the collection of empirical data (Kuhnert et al., 2010; Martin et al., 2011).

\footnotetext{
1 Multi-criteria optimization problems, on the contrary, aim to identify the best solution among a large and potentially infinite set of feasible solutions.
}

\subsection{Objectives of farmland biodiversity indicators and selection procedure}

A set of biodiversity indicators was selected following an iterative approach based on a comprehensive scientific literature review (Dennis et al., 2012), field-testing (Jeanneret et al., 2012), and repeated stakeholder involvement (Pointereau and Langevin, 2012). A stakeholder board (the Stakeholder Advisory Board hereinafter $\mathrm{SAB}$ ) composed of 20 members, including representatives of nature protection NGOs, farmer and consumer organisations, territorial administrations and EU level institutions was involved in the selection process through three workshops and internet consultations (cf. Pointereau and Langevin, 2012 for further details). Audits with 12 local stakeholder groups that provided comments and insights on the indicators also constituted part of the selection process.

The selection process started with a stakeholder meeting, during which an agreement on broad objectives was reached between the stakeholders (Table 1 ).

A literature survey was then carried out, in which hundreds of potential biodiversity indicators were filtered according to scientific criteria and the broad stakeholder objectives. This process resulted in a set of 49 indicators (see Appendix A), which passed a further selection step carried out at the second stakeholder meeting. To this end, each indicator was characterised in a preliminary fact-sheet to ensure the participants' acquaintance with the 49 indicators, and opinions were collected through an internet based questionnaire prior to the second stakeholder meeting. The results were presented during the meeting, each indicator was discussed and a set of 41 indicators was deemed valuable for the field-testing.

The field test was carried out on 192 sampling farms randomly chosen in 12 case study areas, covering the main European farm types and located in major bio-geographical regions $(14,000$ ha altogether; Dennis et al., 2012). Based on the field results, a final set of 23 indicators based on the field measurement of 6 parameters was selected after an information redundancy check (description of the protocol of measurement of the 6 biodiversity parameters is reported in the Supplementary material S1). Information on the scientific consistency, practicability, and feasibility of the 23 indicators was submitted to the stakeholder board together with comments from the 12 local stakeholder groups for the final selection step (Table 2; Herzog et al., 2013).

Feasibility and practicability were also assessed during the fieldtest campaign through a systematic cost/effort data collection. The cost data collection was aggregated per parameter, as the distribution per indicator of specific resources (labour, consumables and equipment) was not operational (i.e. resources were spent for the parameter measurement and not per individual indicator). The six field-measured parameters were: habitat mapping (HM), vegetation (V), wild and domestic bees (B), spiders (S), earthworms (EW), and a farm management questionnaire $(\mathrm{Q})$. The cost collection procedure was specifically designed to allow for the estimation of the costs of a regular monitoring programme (Caughlan and Oakley, 2001). To this end, the simulation of the budgetary requirements of a monitoring programme was based on the empirical data collected during the field survey, and actual labour costs as reported in Levrel et al. (2010) and from the authors' discussions with four consultancy agencies. The cost of the measurement was estimated by employing a cost function in reference to a "standardised" farm characterised by the average features of the farms sampled during the field campaign (i.e. 73 ha, 15 habitat types, $1 \mathrm{~h}$ travel needed to get to the farm) and taking into account the differences in labour costs across the EU Member States (see Targetti et al., 2014 for further details). 
Table 1

Objectives and expectations of biodiversity indicators as perceived by the Stakeholder Advisory Board.

\begin{tabular}{|c|c|}
\hline Objective & Specification \\
\hline $\begin{array}{l}\text { Assessment of the impact of farming practices } \\
\text { on biodiversity }\end{array}$ & $\begin{array}{l}\text { As a major component of sustainability, biodiversity provides services for agricultural production and society and } \\
\text { deserves considerable attention from the wider public }\end{array}$ \\
\hline $\begin{array}{l}\text { Support to agro-environmental policy design } \\
\text { and implementation }\end{array}$ & $\begin{array}{l}\text { An enhanced knowledge base would help to improve the design of environmental policies and increase societal benefits } \\
\text { from public spending }\end{array}$ \\
\hline Labelling of agricultural products & $\begin{array}{l}\text { Certification and labelling are important levers to sustain biodiversity in agricultural lands through market-based } \\
\text { mechanisms }\end{array}$ \\
\hline Raising consumer awareness & $\begin{array}{l}\text { Consumer awareness of biodiversity and an improved understanding of biodiversity is essential to raise societal } \\
\text { awareness }\end{array}$ \\
\hline $\begin{array}{l}\text { Providing standardized protocols and indicators } \\
\text { throughout Europe }\end{array}$ & $\begin{array}{l}\text { Uniform and consistent measurement of biodiversity requires standard methods capable of assessing biodiversity across } \\
\text { different farm types, systems and geographic scales }\end{array}$ \\
\hline
\end{tabular}

Table 2

Farmland biodiversity indicators as proposed by Herzog et al. (2013) for the measurement of European farmland biodiversity. The grouping into parameters follows the logic of data collection, i.e. the data for all indicators of a parameter can be recorded together. For instance, the parameter "Questionnaires" groups both farm management and genetic diversity indicators.

\begin{tabular}{ll}
\hline Parameter & Indicators \\
\hline Habitat (HM) & Habitat richness \\
& Habitat diversity \\
& Average size of habitat patches \\
& Length of linear elements \\
& Crop richness \\
& Percentage of farmland with shrubs \\
& Percentage of farmland with trees \\
Vascular plants (V) & Percentage of semi-natural habitats \\
Wild bees and bumble bees (B) & Number and amount of vascular plant species \\
Earthworms (EW) & Number and amount of wild bee and bumblebee species \\
Spiders (S) & Number and amount of earthworm species \\
Questionnaires (Q) & Number and amount of spider species \\
& Number and amount of different breeds \\
& Number and amount of different varieties \\
& Origin of crops \\
& Total direct and indirect energy input \\
& Intensification/extensification (expenditures on inputs) \\
& Area with use of mineral nitrogen fertiliser \\
& Total nitrogen input \\
& Frequency of field operations \\
& Pesticide use \\
Average stocking rate \\
Grazing intensity \\
\hline
\end{tabular}

The cost simulation was performed taking into account three different strategies that could potentially be implemented: (i) subcontracting to private agencies, (ii) set-up of farmer networks, and (iii) involvement of volunteers. While the involvement of private consultant agencies is the usual approach of public bodies through calls for tenders, (see e.g. LUCAS, Eurostat, 2013), the rationale of the involvement of farmers and volunteer networks lies in the growing interest in bottom-up strategies that seek wider societal involvement in conservation (Devictor et al., 2010; Conrad and Hilchey, 2011; EEA, 2013a, 2013b). In the farmer involvement strategy, travel costs are excluded and the average person day cost of a farmer is hypothesised as a reasonable incentive to carry out the field activities of the species parameters $(\mathrm{V}, \mathrm{B}, \mathrm{S}$, and $\mathrm{EW})$ and the farm questionnaire $(\mathrm{Q})$. In the volunteer involvement strategy, the reimbursement of consumables, vehicle and equipment costs are envisaged for the field collection of the fauna parameters and the identification of species (B, S, and EW), whereas labour is free. In both the farmer and volunteer strategies, technically complex activities, such as habitat mapping and deskwork, are performed by private agencies as in strategy " $i$ ". In the farmer strategy, the identification of fauna species is also performed by private agencies. The costs for training and any post processing activities required to obtain adequate data quality were not considered in the cost analysis.

\subsection{Usefulness of the biodiversity parameters: evaluation framework}

While scientific consistency, practicability, and feasibility were tested in the field, the evaluation of usefulness was performed through a stakeholder questionnaire aimed at assessing the relevance of the final indicator set for three end-user types: administrators, farmers and consumers. To this end, the stakeholder board devised ten usefulness criteria during the 2nd meeting (Table 3 ).

A weight elicitation procedure was performed to derive a set of weights for the six biodiversity parameters $p$ taking into account: (a) the relevance of the parameters on the ten usefulness criteria $c$, and (b) the relevance of the criteria for the three end-user types $u$. Therefore, an evaluation framework consisting of two distinct phases was developed (Fig. 1): Weighting of the relevance of parameters along the criteria (phase 1 ), and weighting of the relevance of the criteria for the different end-users (phase 2).

The evaluation was performed through an ad-hoc questionnaire delivered to the SAB in 2011 after the 3rd stakeholder meeting (the questionnaire is available in the Supplementary material S2). The questionnaire included 30 score judgments for each end-user type (overall 90 judgments per stakeholder) and was composed of two distinct parts: The first part concerned the analysis phase 1 and included 10 questions (e.g. "In your opinion, what is the relevance 
Table 3

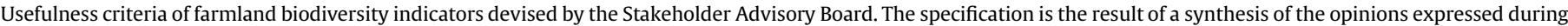
the board meetings.

\begin{tabular}{|c|c|c|}
\hline N. & Stakeholders' usefulness criteria & Specification \\
\hline 1 & Understandable and flexible & $\begin{array}{l}\text { Indicators should convey easy-to-understand information on the biodiversity status and capture numerous } \\
\text { biodiversity-related issues }\end{array}$ \\
\hline 2 & Appropriation by farmers & Indicators should meet farmers' expectations and needs \\
\hline 3 & Appropriation by consumers & Indicators should meet expectations and needs of consumers of agricultural products \\
\hline 4 & Appropriation by administrators & Indicators should meet administrators' expectations and needs \\
\hline 5 & Integrate emblematic species & Indicators should convey information regarding emblematic species (e.g. species which appeal to the public) \\
\hline 6 & $\begin{array}{l}\text { Assess farmer progress (agro-environmental project } \\
\text { progress) }\end{array}$ & Indicators should be sensitive to measure environmental progress at farm level \\
\hline 7 & Assess agricultural policies & Indicators should be sensitive to measure the effectiveness of agricultural policies \\
\hline 8 & Adapted to all types of farming & $\begin{array}{l}\text { Indicators should be able to assess biodiversity of different farm types (i.e. arable farming, animal husbandry, } \\
\text { etc.) }\end{array}$ \\
\hline 9 & Applicable at different scales (field, farm, lan & Indicators should be able to assess biodiversity at field, farm, and landscape scale \\
\hline 10 & $\begin{array}{l}\text { Account for functional biodiversity towards } \\
\text { ecosystem services }\end{array}$ & $\begin{array}{l}\text { Indicators should fit to the assessment of functional biodiversity and provide information regarding ecosystem } \\
\text { services }\end{array}$ \\
\hline
\end{tabular}

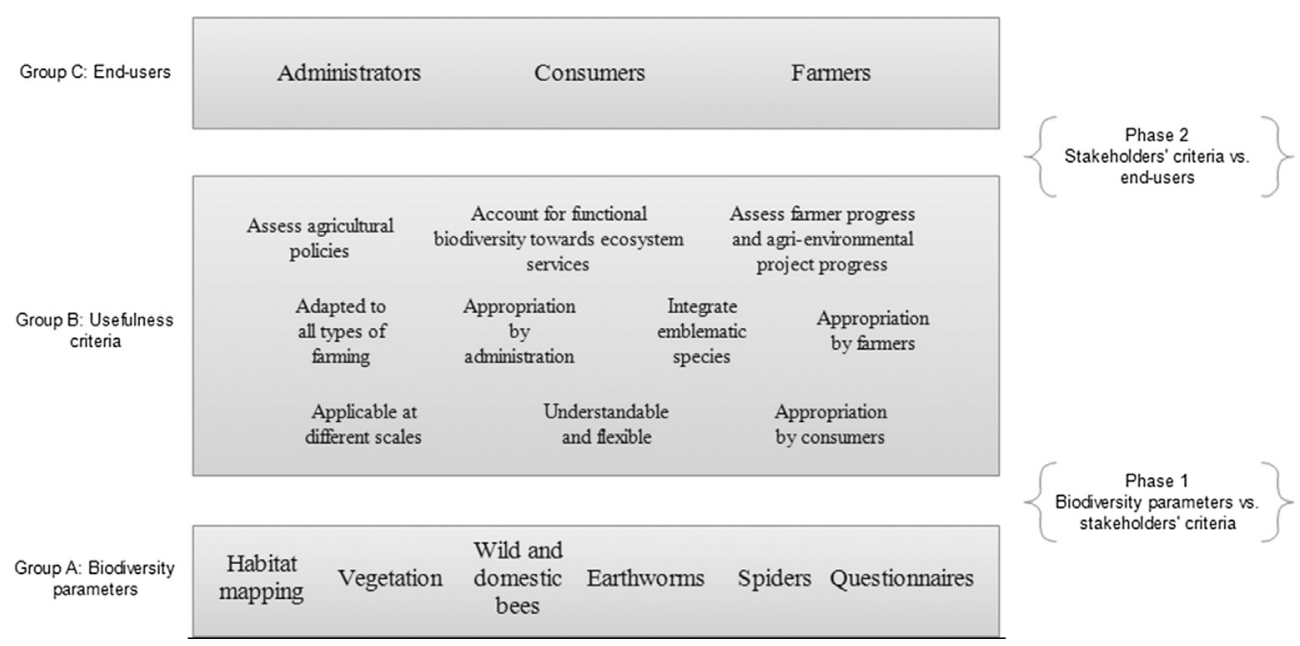

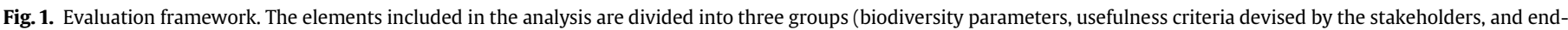

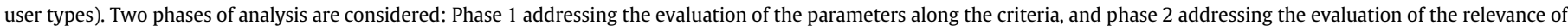
the criteria for the end-users.

of biodiversity parameter p according to criterion c?"). The second part was a cross-table concerning the analysis phase 2 (e.g. "What is the relevance of criterion c for the end-user u?"). At least one questionnaire from each stakeholder affiliation group was returned yielding 11 questionnaires overall (rate of return 0.55; Table 4). An analysis of variance (ANOVA) was performed to identify statistical relevance of the differences of judgments expressed by the stakeholders affiliated to the different groups. Finally, confidence intervals of the average usefulness of the parameters were also estimated by means of bootstrapping. Each judgment set (i.e. 11 judgments) was resampled with 1000 random replicates with replacement. Lower and upper confidence interval (set at $2.5 \%$ and $97.5 \%$ respectively) of the 1000 replicate averages was then estimated (i.e. 1000 replicates per 90 judgments) to evidence overlappings between the usefulness scores of the biodiversity parameters.

The questionnaire was based on direct rating and an absolute scale of measurement. In the first analytical phase, the stakeholder was asked criterion-wise to identify the most relevant parameter in relation to the criterion and to attribute a maximum score (i.e. 9) to that element. Then, relative values from 0 (totally unimportant) to 9 (absolutely important) were attributed to the other parameters. Equal scores were allowed. The absolute scale was adopted following the empirical work of Saaty (2005; see also Miller, 1958), which demonstrates the pertinence of the nine-point scale to cognitive processes and its ability to capture the individual's intensity of preference with a moderate cognitive effort from the respondent. The zero value was specifically added in the present

Table 4

Number of questionnaires returned from the stakeholders of each organisation type.

\begin{tabular}{|c|c|c|}
\hline Affiliation type & Representatives on the stakeholder board (No) & Questionnaires returned (No) \\
\hline NGO Nature protection and environment & 5 & 3 \\
\hline NGO Consumer association & 1 & 1 \\
\hline Farmer organisation & 3 & 2 \\
\hline Territorial and national administration & 3 & 2 \\
\hline Farmer adviser and agrarian institute & 2 & 2 \\
\hline EU institutions & 6 & 1 \\
\hline
\end{tabular}


analysis to include the total absence of importance, which was not necessary in the original procedure based on pairwise comparisons (Harker and Vargas, 1987; Bartolini et al., 2011). The aggregation of the individual judgments was performed by way of the arithmetic mean. The arithmetic mean is the most straightforward method that allows considering each individual judgment of the same importance and can be used when the elicitation is independent (i.e. stakeholders filled-in the questionnaires separately) (Forman and Peniwati, 1998). The set of individual judgments concerning the relevance of the parameters on the criteria (phase 1) was aggregated and normalized on the maximum score value (i.e. 9)

$W_{p, c}=\frac{\sum_{s} w_{p, c}^{s}}{n} * \frac{1}{9}$

where $W_{p, c}=$ biodiversity parameter score on criterion $c$ from analysis phase $1 ; s=$ stakeholder; $c=$ criterion; $p=$ biodiversity parameter; $n=$ number of individual judgments (i.e. 11 ).

To highlight the possible occurrence of compensatory effects between the criteria (i.e. the very good performance of a parameter on a criterion that offsets the very bad performance on another criterion so that the best performing parameter on average may not fit into one or more specific criteria; see Garmendia and Gamboa, 2012; Choo et al., 1999), a cluster analysis was also performed (Euclidean distance, Ward aggregation method; R Development Core Team, 2012). The cluster analysis was performed to highlight groups of criteria according to the vectors of the six parameter scores and hence to highlight specific correspondences between criteria and parameters (Eq. (1)).

In the analysis phase 2 , the stakeholders were asked to score the relevance of the criteria in relation to each end-user type using the same $9+1$ scale of measurement. Similarly, the arithmetic mean was used to aggregate the set of individual judgments concerning the relevance of the criteria for the end-users and using the sum of values as a normalizing coefficient

$W_{c, u}=\frac{\left(\frac{\sum_{s} w_{u, c}^{s}}{n}\right)}{\sum_{u, s}\left(\frac{w_{u, c}^{s}}{n}\right)}$

where $W_{c, u}=$ criteria score for end-user $u$ from analysis phase 2 .

The overall usefulness of parameter $p$ for the end-user $u$ was finally calculated as the product of the weights $W_{p, c}{ }^{*} W_{c, u}$ (Eqs. (1) and (2)), Then, the normalized value of the product was used to express the relative usefulness of each parameter in respect to the full parameter set. The multiplication is coherent with the structure of the evaluation framework where the usefulness of the parameters is dependent on both the relevance across the criteria and the relevance of the criteria across the end-users.

To identify the best monitoring strategy according to costs and usefulness, the results of the stakeholder evaluation was plotted against the costs. The costs of the biodiversity parameter measurement, according to the different strategies, are presented in Table 5.
The cost and usefulness of indicators were integrated by computing the cost/usefulness ratio. The result was considered as a "cost of usefulness" parameter that was used to compare different parameter sets and strategies.

\section{Results}

In general, the opinions expressed by the stakeholders did not highlight significant differences between the considered affiliation groups (ANOVA results are reported in the Supplementary material S3). Major differences were evidenced for the spiders and farm questionnaire parameters $(\mathrm{p}<0.01)$ in connection to the criteria "Account for functional biodiversity towards ecosystem services" (spiders), and "Assess agricultural policies" and "Applicable at different scales" (farm questionnaire).

The cluster analysis yielded four groups of criteria (Fig. 2). Applicability-related criteria ("Adapted to all types of farming" and "Applicable at different scales") were grouped together in cluster 4, which was the most differentiated group in the dendrogram. The other three clusters appeared to be linked to specific end-users as each of them included a specific "appropriation" criterion, i.e. "Appropriation by farmers" in cluster 1, "Appropriation by administration" in cluster 2 and "Appropriation by consumers" in cluster 3. Furthermore, the dendrogram structure pointed to a more evident difference between cluster 3, and clusters 1 and 2 .

The scores of HM, V, S and EW did not show any significant differences across the clusters (Table 6; scores of the six parameters in relation to the stakeholder criteria are reported in the Supplementary material S4). In fact, while the parameters "Habitat mapping" and "Vegetation" ranked in the first positions, "Earthworms" and "Spiders" ranked in the last two positions across all clusters. On the contrary, the parameters "Questionnaire" and "Wild and domestic bees" showed significant differences and higher scores in relation to the "applicability" cluster and the "consumer" cluster respectively.

On average, the criterion "Understandable and flexible" ranked by far as the most relevant criterion with no statistical differences across the three user categories (Table 7). Indeed, the distance between the first and the second ranked criterion (i.e. "Adapted to all types of farming") was higher than the distance between the second and the least important criterion (i.e. "Account for functional biodiversity towards ecosystem services"). As expected, the three "appropriation" criteria ranked first in the respective actor types (e.g. "appropriation by farmers" ranked first for the farmer category) highlighting statistical differences between the user categories $(\mathrm{p}<0.001)$. It is also worth noting that the appropriation criteria related to the other users were at the bottom level of the importance scale for each user (e.g. appropriation by consumers and administrators were the least important criteria for the farmer category). In general, the criteria ranking was rather similar in the administrator and farmer categories, whereas greater differences could be noticed between these two categories and the consumer category. For instance, the second-best criterion for consumers was "Integrate emblematic species". This criterion was ranked in the last positions for both administrators and farmers (i.e. 9th and 8th respectively, $\mathrm{p}<0.001$ ). Similarly, "Assess farmer progress and agri-

Table 5

Estimated costs of the biodiversity parameter measurement. Source: Targetti et al., 2014.

\begin{tabular}{|c|c|c|c|c|c|c|c|}
\hline & $\mathrm{HM}(€)$ & $\mathrm{V}(€)$ & $\mathrm{B}(€)$ & $S(€)$ & $\mathrm{E}(€)$ & $\mathrm{Q}(€)$ & Total $(€)$ \\
\hline Strategy A (professional agency-based) & 894 & 1006 & 1438 & 1993 & 2332 & 513 & 8175 \\
\hline Strategy B (farmer-based fieldwork) & 548 & 493 & 600 & 1196 & 1291 & 251 & 4380 \\
\hline Strategy C (volunteer-based species sampling) & 894 & 1006 & 66 & 88 & 107 & 513 & 2674 \\
\hline
\end{tabular}




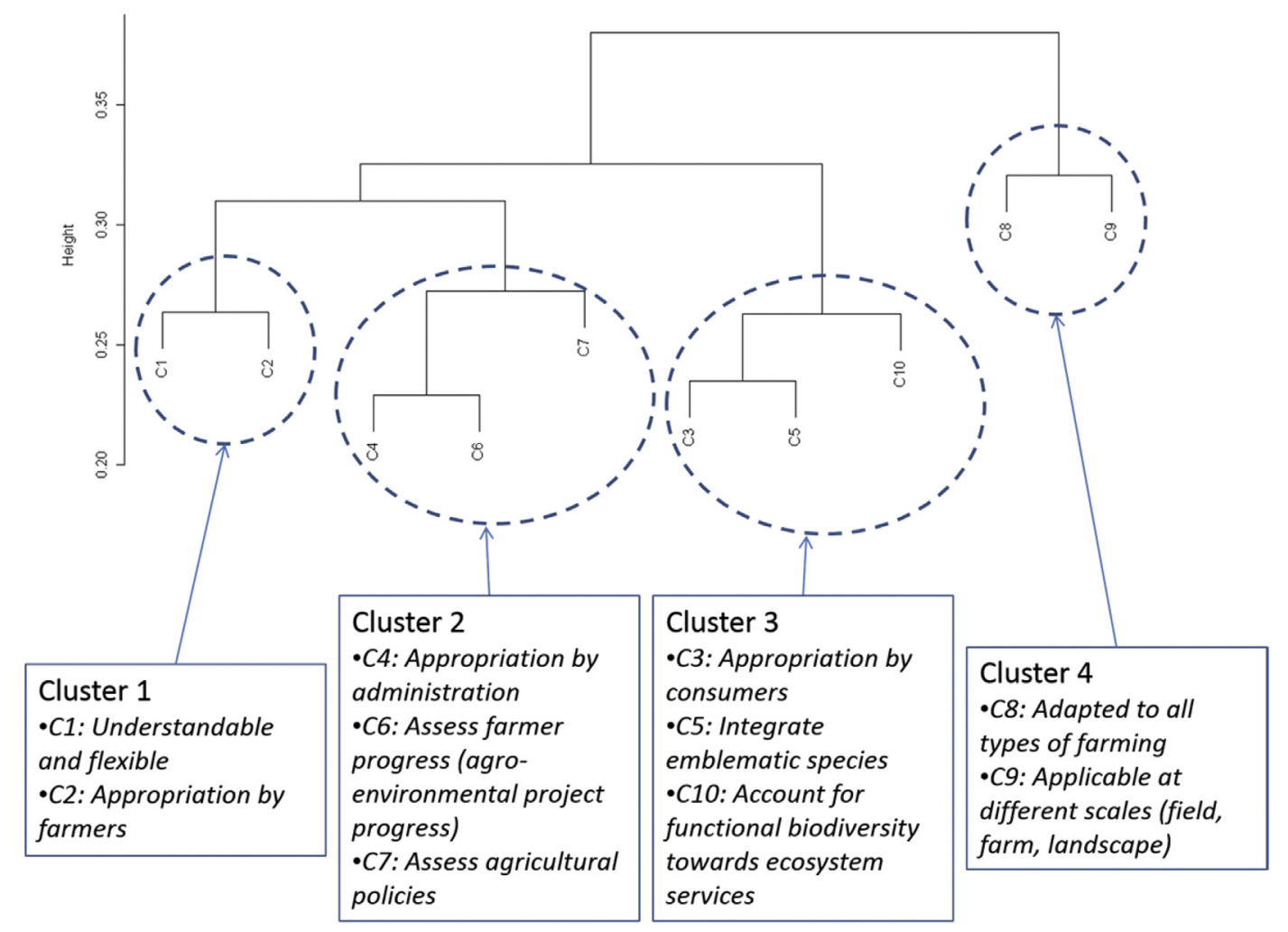

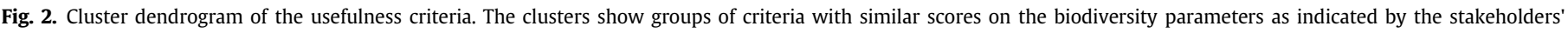
questionnaires.

Table 6

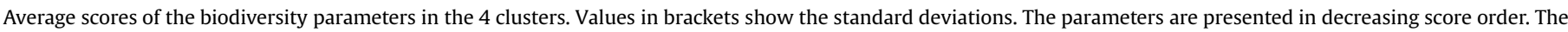

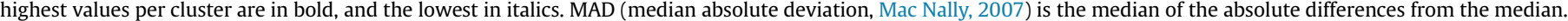
ANOVA F value test; ${ }^{* *} \mathrm{p}<0.01 ;{ }^{* * *} \mathrm{p}<0.001$; ns $=$ not significative.

\begin{tabular}{|c|c|c|c|c|c|c|c|c|c|c|}
\hline & Cluster $1(\%)$ & MAD & Cluster $2(\%)$ & MAD & Cluster $3(\%)$ & MAD & Cluster $4(\%)$ & MAD & Average & \\
\hline Habitat mapping (HM) & $6.8(2.4)$ & 2 & $7.2(2.3)$ & 1 & $6.2(3.0)$ & 2 & $7.9(2.3)$ & 0 & 6.9 & ns \\
\hline Vegetation $(\mathrm{V})$ & $6.6(2.3)$ & 1.5 & $6.3(2.3)$ & 1 & $7.2(1.8)$ & 2 & $6.5(2.3)$ & 1 & 6.7 & ns \\
\hline Farm questionnaire $(\mathrm{Q})$ & $6.1(3.3)$ & 3 & $6.7(2.9)$ & 2 & $4.1(2.8)$ & 1 & $7.5(1.5)$ & 2 & 6.0 & $* * *$ \\
\hline Wild and domestic bees (B) & $5.9(2.7)$ & 2 & $4.8(2.2)$ & 2 & $6.9(2.3)$ & 2 & $5.4(2.6)$ & 3.5 & 5.8 & $* *$ \\
\hline Earthworms (EW) & $4.4(3.0)$ & 2.5 & $4.2(2.5)$ & 2 & $4.5(2.8)$ & 2 & $4.5(3.3)$ & 3 & 4.4 & ns \\
\hline Spiders (S) & $3.4(2.1)$ & 1 & $3.7(2.1)$ & 2 & $4.0(2.5)$ & 3 & $4.6(3.3)$ & 1 & 3.9 & ns \\
\hline
\end{tabular}

Table 7

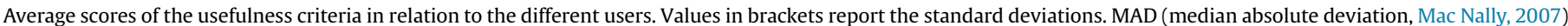

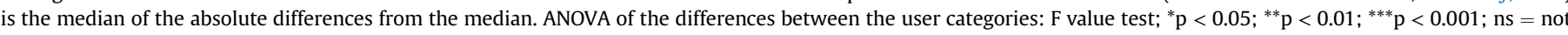
significative.

\begin{tabular}{|c|c|c|c|c|c|c|c|c|}
\hline & \multicolumn{2}{|c|}{ Administrators } & \multicolumn{2}{|l|}{ Farmers } & \multicolumn{2}{|c|}{ Consumers } & \multicolumn{2}{|c|}{ Average } \\
\hline & Mean & MAD & Mean & MAD & Mean & MAD & & \\
\hline Understandable and flexible & $7.9(1.4)$ & 0 & $8.5(0.9)$ & 0 & $7.3(1.6)$ & 2 & 7.9 & ns \\
\hline Adapted to all types of farming & $6.9(2.9)$ & 1 & $7.4(1.7)$ & 1 & $5.4(2.5)$ & 2 & 6.6 & ns \\
\hline Appropriation by farmers & $5.7(2.2)$ & 1 & $8.8(0.6)$ & 0 & $4.3(1.4)$ & 1 & 6.3 & $* * *$ \\
\hline Appropriation by consumers & $4.6(2.2)$ & 1 & $4.82 .1)$ & 2 & $9.0(0.0)$ & 0 & 6.2 & $* * *$ \\
\hline Assess farmer progress and agri-environmental project progress & $6.9(1.9)$ & 2 & $6.9(2.1)$ & 1 & $4.9(2.4)$ & 1 & 6.2 & * \\
\hline Applicable at different scales (field. farm. landscape and Europe) & $7.1(2.6)$ & 1 & $6.0(2.4)$ & 1 & $5.1(2.5)$ & 3 & 6.1 & ns \\
\hline Assess the agricultural policies (AEM, Biodiversity Action Plans, cross-compliance...) & $7.3(2.5)$ & 1 & $6.3(1.8)$ & 1 & $4.4(2.2)$ & 3 & 6.0 & $*$ \\
\hline Integrate emblematic species & $4.8(1.8)$ & 1 & $5.1(2.4)$ & 2 & $7.9(1.4)$ & 1 & 5.9 & $* * *$ \\
\hline Appropriation by administration & $8.5(1.0)$ & 0 & $4.8(2.4)$ & 2 & $3.6(2.1)$ & 2 & 5.6 & $* * *$ \\
\hline Account for functional biodiversity towards ecosystem services & $5.6(2.0)$ & 1 & $5.2(2.0)$ & 2 & $5.3(1.3)$ & 1 & 5.4 & $\mathrm{~ns}$ \\
\hline
\end{tabular}

environmental project progress", and "Assess agricultural policies" were more relevant for the administrator and farmer categories in comparison to the consumer category ( $p<0.05$ ).

The average weights of the six biodiversity parameters across the three user categories ranged between 0.43 (for "Spiders") and 0.77 (for "Habitat mapping") (Table 8). The bootstrap analysis did not evidence any overlappings between the upper and lower confidence intervals between the biodiversity parameters (the 
bootstrap results are reported in the Supplementary material S5). "Habitat mapping" showed the highest relevance and "Vegetation" was the second best parameter in all of the user categories, whereas the weights of the parameters "Spiders" and "Earthworms" were the lowest across all users. There were major differences in the consumer category where the weights of HM and V were particularly close and B ranked better than $\mathrm{Q}$.

Following the average parameter ranking in Table 8 , the costs of different sets is plotted against the relative usefulness of each set (Fig. 3). On the x-axis, the cumulated "usefulness", as resulting from Table 8, is indicated for "Habitat mapping" (set 1), for "Habitat mapping" + "Vegetation" (set 2), etc. In the full set case, the cost estimated for the private agency strategy was by far the highest, whereas the volunteer strategy cost was the lowest. Farmer involvement allowed for the lowest cost per unit of usefulness up until set N. 4 (which provides more than $75 \%$ of cumulated usefulness). Furthermore, in sets N. 1, 2 and 3, the marginal cost of usefulness was rather stable in all of the three data collection strategies (i.e. the variation of the cost per unitary variation of usefulness is close to zero as shown by the slope of the lines), whereas a strong increase in marginal costs can be seen going from set 3 to the full set for the private and farmer data collection strategies. On the contrary, marginal costs were generally decreasing or equal to zero for the volunteer data collection strategy from set N. 3 to the full set (i.e. the slope of the line is $\approx 0$ ).

\section{Discussion}

Matching the evaluation of costs and expectations of end-users allowed to highlight the potential of different biodiversity parameters and related indicators to convey ecological information efficiently. Budgetary limitations often hamper the implementation or continuation of many monitoring programmes (McDonaldMadden et al., 2011), and failing to provide an exhaustive analysis of costs and benefits can exacerbate this problem (Targetti et al., 2012). The objective of the analysis was, however, not to reduce the full parameter set which was developed as a baseline capable of meeting scientific requirements for an effective biodiversity monitoring programme (Herzog et al., 2013). The analysis provided in this paper suggests how the monitoring of farmland biodiversity can be attractive to different end-users and explore different funding strategies.

The main limitation of this work is the relatively low number of questionnaires on which the results are based. Even though results would benefit from the involvement of a greater number of experts, several existing studies are based on comparable numbers of questionnaires (e.g. Kuhnert et al., 2010; Gregory and Keeney, 1994; Mac Nally, 2007; Redpath et al., 2004; Ananda and Herath, 2009). Moreover, the possibility of collecting the opinions of committed and well-informed stakeholders that were deeply involved during the indicator selection procedure presented a unique opportunity. By combining their involvement in the selection process and their different professional backgrounds (e.g. administration, farming or

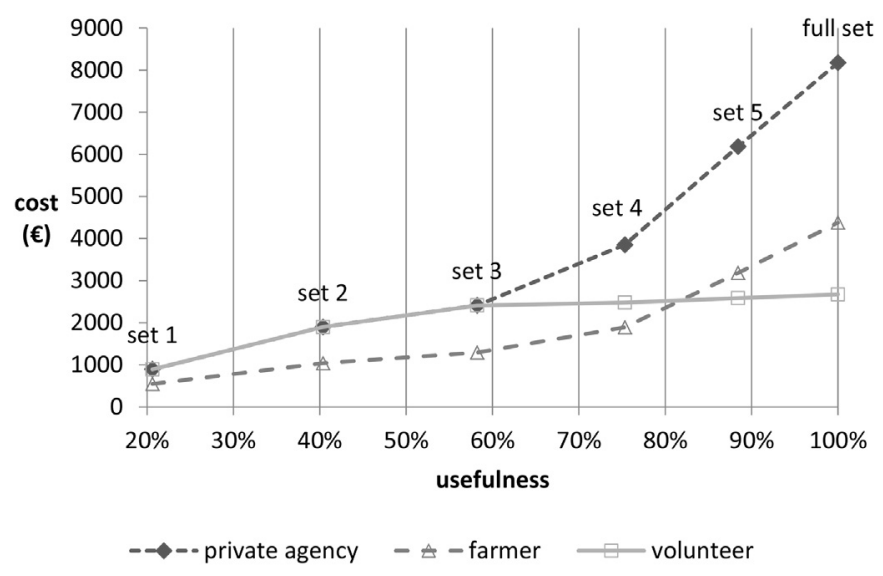

Fig. 3. Trends of cost vs. relative usefulness attached to different parameter set-ups and for different monitoring strategies (private agency, farmer and volunteer strategies). The parameter set N. 1 includes HM; set N. 2 HM and V; set N. 3 HM, V and Q; set N. 4 HM, V, Q and B; set N. 5 HM, V, Q, B and EW.

consumer organisations), they can be considered to be a rigorous and valuable panel for the quantitative assessment of the usefulness of biodiversity parameters in connection to potential endusers. The fact that only minor differences were identified in the opinions expressed by the stakeholder affiliation groups may be related to the low number of questionnaires, but may also stem from the long selection procedure (including the three meetings) that allowed stakeholders to exchange opinions and ideas and contributed to the reduction in differences between the judgments.

The habitat mapping, vegetation, and questionnaire parameters ranked in the first positions along the 4 criteria clusters. Major differences were highlighted in cluster 3 related to emblematic species and functional biodiversity, together with appropriation by consumer criteria. In that case, the top rated parameters were $\mathrm{V}$ and $B$. This finding indicates how conveying biodiversity information to consumers of agricultural products may require more specific biodiversity parameters in comparison to other end-users, perhaps showing a preference for indicators that are easily noticeable or visible or with a more straightforward connection with biodiversity.

Nevertheless, a common set of parameters seemed to meet the expectations of all of the different end-users. Indeed, four parameters (HM, V, Q and B) out of the six analysed would make it possible to cover more than $75 \%$ of the usefulness of the full parameter set and to reduce the budget requirement by more than $50 \%$ in the case of the private agency data collection strategy. According to other works (e.g. Gardner et al., 2008), this is due to the fact that the high performance parameters were also the least expensive (referring to the private costs). On the other hand, costs cannot be the only factor for parameter selection. For instance, the farm questionnaire would rank as the best performing parameter if one considers the usefulness/cost ratio. However, Q can only deliver

Table 8

Weights attributed to the usefulness of the biodiversity parameters in relation to the end-users. Parameters are reported in decreasing order of average usefulness.

\begin{tabular}{|c|c|c|c|c|c|}
\hline & \multicolumn{3}{|c|}{ End-user categories } & \multirow[t]{2}{*}{ Average } & \multirow[t]{2}{*}{ Normalized average (\%) } \\
\hline & Administration & Farmers & Consumers & & \\
\hline Habitat mapping (HM) & 0.780 & 0.774 & 0.757 & 0.771 & 21 \\
\hline Vegetation $(\mathrm{V})$ & 0.733 & 0.736 & 0.751 & 0.740 & 20 \\
\hline Farm questionnaire $(\mathrm{Q})$ & 0.682 & 0.678 & 0.634 & 0.666 & 18 \\
\hline Wild and domestic bees (B) & 0.625 & 0.636 & 0.664 & 0.641 & 17 \\
\hline Earthworms (EW) & 0.490 & 0.494 & 0.489 & 0.491 & 13 \\
\hline Spiders (S) & 0.433 & 0.431 & 0.434 & 0.433 & 11 \\
\hline
\end{tabular}


information about farm management practices and the genetic diversity of crops and husbandry animals (Last et al., 2014). It does not inform about the actual status of farmland habitats and species, which needs to be recorded in the field. The joint analysis of biodiversity status records and farm management practice indicators then makes it possible to investigate relations between causes (e.g. pesticide application) and effects (e.g. number and type of plant species). However, in our analysis the range of usefulness scores of the six parameters was less relevant in comparison to the cost differences between the three data collection strategies. In fact, the marginal costs were clearly divergent between the private and volunteer strategies as soon as faunistic indicators were added to "Habitat mapping", "Vegetation", and "Questionnaire" (from set N. 3 onward). Therefore, the cost of the measurement -and even more the marginal costs than the usefulness rank- ended up being the factor with the most relevant impact on the identification of the high performance parameters.

Our findings also point to the possibility of designing efficient monitoring programmes based on a mixed approach, such as farmer engagement for the field data collection of the "Vegetation" and "Questionnaire" parameters and volunteer networks for the fauna parameter sampling. Though relevant, this possibility may be hindered by several drawbacks that require attentive evaluation. For instance, the exchange of information may be logistically complex and training may be required hence entailing further costs that may ultimately exceed savings. Moreover, additional post processing and quality control activities and a more intense sampling density are likely required to cope with the variability introduced by the multitude of observers used in the farmer and volunteer strategies. Yet the main limitation of the bottom-up approaches is likely related to the need for further research capable of assessing the willingness of farmers and volunteers to participate in such programmes and to account for the additional benefits that bottom-up approach allows (e.g. Dickinson et al., 2010; EEA, 2013b).

Findings of Lüscher et al. (2014) show that the vegetation parameter is one of the most appropriate parameter for delivering reliable information to farmers. In line with that work, our evidence seems to support that the $\mathrm{V}$ parameter (together with HM, which is required for the sampling design) is able to combine scientific effectiveness, economic feasibility and usefulness for farmers. Moreover, the vegetation parameter is one of the top-ranked parameter for delivering information to administrators and consumers. The trend of marginal costs also highlights that adding the "Questionnaire" parameter to "Habitat mapping" and "Vegetation" is convenient with respect to the cost per unit of usefulness. Indeed this set of farm management, habitat and plant species parameters is commonly employed in existing biodiversity monitoring programmes (e.g. the Countryside Survey - www.countrysidesurvey. org.uk; NILS). Implementation of the fauna parameters would, however, be necessary to reach a comprehensive insight. The marginal cost trends suggest that the recording of "Bees", "Spiders" and "Earthworms" could make use of voluntary networks to maximise the efficiency of the monitoring programme. It should be investigated, however, whether, to achieve similar coverage of the existing bird and butterfly monitoring efforts, it is feasible to set-up similar networks of volunteers interested in the sampling of bees, spiders, and earthworms (Levrel et al., 2010; Schmeller et al., 2012; EEA, 2013b).

\section{Conclusions}

As stated by Spangenberg et al. (2014), “Conservation without budget is just conversation” (Spangenberg et al., 2014, p. 31). Even if a budget is available for biodiversity measurement, it will inevitably be limited, hence, making it essential that public funds are spent as effectively as possible. In addition, overlooking enduser expectations may hamper the effectiveness of monitoring schemes which would likely result in opportunities for public support and other funding sources being missed. Therefore, knowledge and information about biodiversity and the capacity of indicators to bridge the scientific discourse to the wider society and specific key actors are necessary features for a reliable and enduring evaluation of biodiversity trends.

An assessment of cost/usefulness trade-offs should be complementary to an analysis of the effectiveness and the scientific reliability of the indicators. Very often, the usefulness of biodiversity indicators is neglected by the scientific literature. Certainly, the focus on reliable ecological quantification is an essential part of any biodiversity indicator evaluation. At the same time, situations in which available funding for biodiversity monitoring is inadequate may occur independently of the scientific reliability. In this case, information on costs and usefulness is likely to enhance the effectiveness of the programme and will provide more consistent justification to public expenditures.

Our analysis points to the need for further research on the marginal costs of information and the selection of indicators based on a differentiated array of aspects (e.g. usefulness, feasibility, together with scientific consistency; Noss, 1990; Chess et al., 2005; Turnhout et al., 2007) as a valuable and intelligent approach to the design of efficient monitoring programmes. Such an analysis makes it possible to implement and explore mixed strategies involving different kinds of actors (private agencies, farmers and volunteers) at different levels and stages that are able to maximise the environmental benefits that can be achieved with available funds.

\section{Acknowledgements}

Part of this research was granted by the EU-FP7 Project BioBio "Indicators for biodiversity in organic and low-input farming systems", contract No KBBE 227161. www.biobio-indicator.org. ST acknowledges support from Labex OT-Med www.otmed.fr. The contribution of IRG was financed by the EU BON project (www.eubon.eu, EU FP 7, Grant no. 308454). This work does not necessarily reflect the view of the European Union and in no way anticipates the Commission's future policy in this area. The authors wish to thank the members of the BioBio Stakeholder Advisory Board for their contribution and support.

\section{Appendix A. Supplementary data}

Supplementary data related to this article can be found at http:// dx.doi.org/10.1016/j.jenvman.2015.08.044.

\section{Appendix}

49 potential farmland biodiversity indicators which were evaluated by the Stakeholder Advisory Board (2nd meeting).

\section{A. Genetic diversity indicators}

A1) Number and amount of different breeds per species* A2) Information on breeding practices ("on-farm" bull, artificial insemination,...)

A3) Where available: pedigree of the herd

A4+ A5) Number, amount and origin of different cultivars/ landraces/accessions per species*

A6) Information on seed propagation practices (on farm multiplication, sharing with neighbours etc) 
A7) Where possible: description of the cultivars based on IPGR descriptors (through the farmer)

A8) Where available: pedigree information on the cultivars grown

A9) Where available number and amount of different cultivars A10) Information on seed propagation practices and amount of re-seeding

\section{B. Species diversity indicators}

B1) Flowering plants of cultivated forage and food crops *

B2) Flowering plants of semi-natural habitats*

B3) Lepidoptera - butterflies

B4) Earthworms*

B5) Hymenoptera - ants

B6) Bird species richness

B7) Small mammals

B8) Araneae -spiders*

B9) Hymenoptera - bees and wasps*

B10) Carabid beetles

B11) Dipterasyrphidaehoverflies

B12) Bat activity

\section{Habitat diversity indicators}

C1) Habitat patch density

C2) Habitat richness*

C3) Habitat diversity*

C4) Number of crops in rotation*

C5) Percentage area of arable land

C6) Percentage area of permanent grassland

C7) Percent of tree cover*

C8) Cover of shrub layer*

C9) Availability of nitrogen, humidity, etc.

C10) Weeds in crops

C12) Vegetation composition: Share of valuable habitats*

C13) Linear elements: Hedgerows; grassy strips between fields;

streams, rivers \& lakes; stone walls, terrace walls*

C14) Multispecies grassland swards

C15) Grassland quality

\section{Farm management indicators}

D1) Diversity of enterprises at the farm

D2) Average stocking rates (livestock units/ha) on farm*

D3) Area of land without use of mineral-based fertilisers *

D4) N-input*

D5) Input or direct and indirect energy for crop production*

D6) Certified as Organic

D7) IRENA Indicator 1: Area under agri-environment support

D8) IRENA Indicator 15: Intensification/extensification*

D9) Pesticide Use - Treatment Frequency Indicator*

D10) Area of land without/with reduced use of chemical pesticides

D11) Frequency and timing of field operations*

D12) Grazing intensity*

*Indicators which were retained after field testing and which are part of the BioBio indicator set (either as such or slightly modified; www.biobio-indicator.org).

\section{References}

Ananda, J., Herath, G., 2009. A critical review of multi-criteria decision making methods with special reference to forest management and planning. Ecol. Econ. 68, 2535-2548. http://dx.doi.org/10.1016/j.ecolecon.2009.05.010.

Armsworth, P.R., Acs, S., Dallimer, M., Gaston, K.J., Hanley, N., Wilson, P., 2012. The cost of policy simplification in conservation incentive programs. Ecol. Lett. 15, 406-414.

Balmford, A., Gaston, K.J., 1999. Why biodiversity surveys are good value. Nature 398, 204-205.

Balvanera, P., Pfisterer, A.B., Buchmann, N., He, J.-S., Nakashizuka, T., Raffaelli, D., Schmid, B., 2006. Quantifying the evidence for biodiversity effects on ecosystem functioning and services. Ecol. Lett. 9, 1146-1156.

Bartolini, F., Gallerani, V., Viaggi, D., 2011. What do agri-environmental measures actually promote? an investigation on AES objectives for the EU 2000-2006 rural development program. Span. J. Agric. Res. 9 (1), 7-21.

Beaufoy, G., Cooper, T., 2009. The application of the high nature value impact indicator. Eur. Communities 38. Available at: http://ec.europa.eu/agriculture/ rurdev/eval/hnv/guidance_annexes_en.pdf (accessed on: March 2015).

Bell, S., Morse, S., 2013. Towards an understanding of how policy making groups use indicators. Ecol. Indic. 35, 13-23.

Bell, S., Morse, S., Shah, R., 2012. Understanding stakeholder participation in research as part of sustainable development. J. Environ. Manage. 101, 13-22. http://dx.doi.org/10.1016/j.jenvman.2012.02.004.

Bockstaller, C., Guichard, L., Keichinger, O., Girardin, P., Galan, M.B., Gaillard, G., 2009. Comparison of methods to assess the sustainability of agricultural systems. A review. Agron. Sustain. Dev. 29, 223-235.

Bommarco, R., Kleijn, D., Potts, S.G., 2013. Ecological intensification: harnessing ecosystem services for food security. Trends Ecol. Evol. 28, 230-238. http:// dx.doi.org/10.1016/j.tree.2012.10.012.

Brooks, T.M., Lamoreux, J.F., Sobéron, J., 2014. IPBES is not IPCC. Trends Ecol. Evol. $29,543-545$.

Caughlan, L., Oakley, K.L., 2001. Cost considerations for long-term ecological monitoring. Ecol. Indic. 1, 123-134.

Chess, C., Johnson, B.B., Gibson, G., 2005. Communicating about environmental indicators. J. Risk Res. 8, 63-75.

Choo, E.U., Bertram, S., Wedley, W., 1999. Interpretation of criteria weights in multicriteria decision making. Comput. Ind. Eng. 37, 527-541.

Cong, R.G., Smith, H.G., Olsson, O., Brady, M., 2014. Managing ecosystem services for agriculture: will landscape-scale management pay? Ecol. Econ. 99, 53-62. http://dx.doi.org/10.1016/j.ecolecon.2014.01.007.

Conrad, C.C., Hilchey, K.G., 2011. A review of citizen science and community-based environmental monitoring: issues and opportunities. Environ. Monit. Assess. $176(1-4), 273-291$.

Dale, V.H., Polasky, S., 2007. Measures of the effects of agricultural practices on ecosystem services. Ecol. Econ. 64, 286-296. http://dx.doi.org/10.1016/ j.ecolecon.2007.05.009.

Danielsen, F., Burgess, N., Balmford, A., 2005. Monitoring matters: examining the potential of locally-based approaches. Biodivers. Conserv. 14, 2507-2542.

Dennis, P., Bogers, M.M.B., Bunce, R.G.H., Herzog, F., Jeanneret, P., 2012. Biodiversity in Organic and Low-input Farming Systems. Handbook for Recording Key Indicators. Wageningen, Alterra-Report 2308. Available at: http://www.biobioindicator.org/deliverables/D22.pdf (accessed on: March 2015).

Devictor, V., Whittaker, R.J., Beltrame, C., 2010. Beyond scarcity: citizen science programmes as useful tools for conservation biogeography. Divers. Distrib. 16 (3), 354-362.

Dickinson, J.L., Zuckerberg, B., Bonter, D.N., 2010. Citizen science as an ecological research tool: challenges and benefits. Annu. Rev. Ecol. Evol. Syst. 41, 149-172. http://dx.doi.org/10.1146/annurev-ecolsys-102209-144636.

Dudley, N., Baldock, D., Nasi, R., Stolton, S., 2005. Measuring biodiversity and sustainable management in forests and agricultural landscapes. Philos. Trans. R. Soc. Lond. B. Biol. Sci. 360, 457-470. http://dx.doi.org/10.1098/rstb.2004.1593.

European Commission, 2011. The EU Biodiversity Strategy to 2020. Brussels. Available at: http://ec.europa.eu/environment/nature/info/pubs/docs/ brochures/2020\%20Biod\%20brochure\%20final\%20lowres.pdf (accessed on: March 2015).

European Environment Agency, 2013a. Science for Environment Policy In-depth Report: Environmental Citizen Science. Copenhagen. Available at: http://ec. europa.eu/environment/integration/research/newsalert/pdf/IR9.pdf (accessed on: January 2015).

European Environment Agency, 2013b. Biodiversity Monitoring in Europe. Copenhagen. Available at: http://www.eea.europa.eu/publications/biodiversitymonitoring-in-europe (accessed on: September 2014).

Eurostat, 2013. LUCAS the EU's Land Use and Land Cover Survey. European Union, 2013. Available at: http://epp.eurostat.ec.europa.eu/cache/ITY_OFFPUB/KS-0313-587/EN/KS-03-13-587-EN.PDF (accessed on: January 2015).

Favreau, J.M., Drew, C.A., Hess, G.R., Rubino, M.J., Koch, F.H., Eschelbach, K., 2006. Recommendations for assessing the effectiveness of surrogate species approaches. Biodivers. Conserv. 15, 3949-3969. http://dx.doi.org/10.1007/s10531005-2631-1.

Firbank, L., Bradbury, R.B., McCracken, D.I., Stoate, C., 2012. Delivering multiple ecosystem services from enclosed farmland in the UK. Agric. Ecosyst. Environ. 166, 65-75.

Firbank, L.G., Perry, J.N., Squire, G.R., Bohan, D.A., Brooks, D.R., Champion, G.T., 
Clark, S.J., Daniels, R.E., Dewar, A.M., Haughton, A.J., Hawes, C., Heard, M.S., Hill, M.O., May, M.J., Osborne, J.L., Rothery, P., Roy, D.B., Scott, R.J., Woiwod, I.P., 2003. The Implications of Spring-Sown Genetically Modified Herbicide-tolerant Crops for Farmland Biodiversity: a Commentary on the Farm Scale Evaluations of Spring Sown Crops, 085521-036-2. http://www.defra.gov.uk/environment/ $\mathrm{gm} / \mathrm{fse} /$ index.htm.

Forman, E., Peniwati, K., 1998. Aggregating individual judgments and priorities with the analytic hierarchy process. Eur. J. Oper. Res. 108 (1), 165-169.

Funtowicz, S., Ravetz, J.R., 1994. Emergent complex systems. Futures 26 (6), $568-582$.

Gardner, T.A., Barlow, J., Araujo, I.S., Ávila-Pires, T.C., Bonaldo, A.B., Costa, J.E., Esposito, M.C., Ferreira, L.V., Hawes, J., Hernandez, M.I.M., Hoogmoed, M.S., Leite, R.N., Lo-Man-Hung, N.F., Malcolm, J.R., Martins, M.B., Mestre, L.A.M., Miranda-Santos, R., Overal, W.L., Parry, L., Peters, S.L., Ribeiro-Junior, M.A., Da Silva, M.N.F., Da Silva Motta, C., Peres, C.A., 2008. The cost-effectiveness of biodiversity surveys in tropical forests. Ecol. Lett. 11, 139-150. http://dx.doi.org/ 10.1111/j.1461-0248.2007.01133.x.

Garmendia, E., Gamboa, G., 2012. Weighting social preferences in participatory multi-criteria evaluations: a case study on sustainable natural resource management. Ecol. Econ. 84, 110-120. http://dx.doi.org/10.1016/ j.ecolecon.2012.09.004.

Gass, S.I., Rapcsak, T., 1998. A note on synthesizing group decisions. Decis. Support Syst. 22, 59-63.

Geijzendorffer, I.R., Targetti, S., Schneider, M.K., Brus, D.J., Jeanneret, P., Jongman, R.H.G., Knotters, M., Viaggi, D., Angelova, S., Arndorfer, M., Bailey, D., Balázs, K., Báldi, A., Bogers, M.M.B., Bunce, R.G.H., Choisis, J.-P., Dennis, P., Eiter, S., Fjellstad, W., Friedel, J.K., Gomiero, T., Griffioen, A., Kainz, M., Kovács-Hostyánszki, A., Lüscher, G., Moreno, G., Nascimbene, J., Paoletti, M.G., Pointereau, P., Sarthou, J.P., Siebrecht, N., Staritsky, I., Stoyanova, S., Wolfrum, S. and Herzog, F., How much would it cost to monitor farmland biodiversity in Europe? J. Appl. Ecol., (in press).

Goldman, R.L., Thompson, B.H., Daily, G.C., 2007. Institutional incentives for managing the landscape: inducing cooperation for the production of ecosystem services. Ecol. Econ. 64, 333-343.

Goodwin, P., Wright, G., 2009. Decision Analysis for Management Judgment, fourth ed. Wiley \& Sons.

Gregory, R., Keeney, R.L., 1994. Creating policy alternatives using stakeholder values. Manag. Sci. 40 (8), 1035-1048.

Hagan, J.M., Whitman, A.A., 2006. Biodiversity indicators for sustainable forestry: simplifying complexity. J. For. 104, 203-210.

Hanley, N., Banerjee, S., Lennox, G.D., Armsworth, P.R., 2012. How should we incentivize private landowners to produce more biodiversity? Oxf. Rev. Econ. Policy 28, 93-113. http://dx.doi.org/10.1093/oxrep/grs002.

Harker, P.T., Vargas, L.G., 1987. The theory of ratio scale estimation: Saaty's analytic hierarchy process. Manage. Sci. 33 (11), 1383-1403.

Heink, U., Kowarik, I., 2010. What criteria should be used to select biodiversity indicators? Biodivers. Conserv. 19, 3769-3797. http://dx.doi.org/10.1007/ s10531-010-9926-6.

Herzog, F., Jeanneret, P., Ammari, Y., Angelova, S., Arndorfer, M., Bailey, D., Balázs, K., Báldi, A., Bogers, M., Bunce, R.G.H., Choisis, J.-P., Cuming, D., Dennis, P., Dyman, T., Eiter, S., Elek, Z., Falusi, E., Fjellstad, W., Frank, T., Friedel, J.K., Garchi, S., Geijzendorffer, I.R., Gomiero, T., Jerkovich, G., Jongman, R.H.G., Kainz, M., Kakudidi, E., Kelemen, E., Kölliker, R., Kwikiriza, N., KovácsHostyánszki, A., Last, L., Lüscher, G., Moreno, G., Nkwiine, C., Opio, J., Oschatz, M.-L., Paoletti, M.G., Penksza, K., Pointereau, P., Riedel, S., Sarthou, J.-P., Schneider, M.K., Siebrecht, N., Sommaggio, D., Stoyanova, S., Szerencsits, E., Szalkovski, O., Targetti, S., Viaggi, D., Wilkes-Allemann, J., Wolfrum, S., Yashchenko, S., Zanetti, T., 2013. Measuring farmland biodiversity. Solutions 4 (4), 52-58.

Hoffmann, A., Penner, J., Vohland, K., Cramer, W., Doubleday, R., Henle, K., Kõljalg, U., Kühn, I., Kunin, W.E., Negro, J.J., Penev, L., Rodríguez, C., Saarenmaa, H., Schmeller, D.S., Stoev, P., Sutherland, W.J., Tuama, E.O., Wetzel, F.T., Häuser, C.L., 2014. Improved access to integrated biodiversity data for science, practice, and policy - the European Biodiversity Observation Network (EU BON). Nat. Conserv. 6, 49-65.

James, A.N., Gaston, K.J., Balmford, A., 1999. Balancing the Earth's accounts. Nature 401, 323-324

Jeanneret, P., Lüscher, G., Schneider, M., Arndorfer, M., Last, L., Wolfrum, S. Balázs, K., Bailey, D., Bogers, M.M.I., Dennis, P., Eiter, S., Fjellstad, W., Friedel, J.K. Geijzendorffer, I.R., Gomiero, T., Herzog, F., Jongman, R.H.G., Kainz, M., Kovács, A., Kölliker, R., Moreno, M., Paoletti, M., Sarthou, J.P., Stoyanova, S., 2012. Report on Scientific Analysis Containing an Assessment of Performance of Candidate Farming and Biodiversity Indicators and an Indication about the Cost of Indicator Measurements. Deliverable 4.1. Available at: http://www.biobioindicator.org/deliverables/D41.pdf (accessed on: March 2015).

Kleijn, D., Kohler, F. Báldi, A., Batáry, P. Concepción, E.D., Clough, Y., Díaz, M., Gabriel, D., Holzschuh, A., Knop, E., Kovács, A., Marshall, E.J.P., Tscharntke, T., Verhulst, J., 2009. On the relationship between farmland biodiversity and landuse intensity in Europe. Proc. R. Soc. B Biol. Sci. 276, 903-909.

Kleijn, D., Rundlöf, M., Scheper, J., Smith, H.G., Tscharntke, T., 2011. Does conservation on farmland contribute to halting the biodiversity decline? Trends Ecol. Evol. 26, 474-481.

Kou, G., Miettinen, K., Shi, Y., 2011. Multiple criteria decision making: challenges and advancements. J. Multi-Crit. Decis. Anal. 18, 1-4.

Kuhnert, P.M., Martin, T.G., Griffiths, S.P., 2010. A guide to eliciting and using expert knowledge in Bayesian ecological models. Ecol. Lett. 13, 900-914. http:// dx.doi.org/10.1111/j.1461-0248.2010.01477.x.

Kuhnert, P.M., Martin, T.G., Mengersen, K., Possingham, H.P., 2005. Assessing the impacts of grazing levels on bird density in woodland habitat: a Bayesian approach using expert opinion. Environmetrics 16, 717-747. http://dx.doi.org/ 10.1002/env.732.

Last, L., Arndorfer, M., Balázs, K., Dennis, P., Dyman, T., Fjellstad, W., Friedel, J.K., Herzog, F., Jeanneret, P., Lüscher, G., Moreno, G., Kwikiriza, N., Gomiero, T. Paoletti, M.G., Pointereau, P., Sarthou, J.-P., Stoyanova, S., Wolfrum, S Kölliker, R., 2014. Indicators for the on-farm assessment of crop cultivar and livestock breed diversity: a survey-based participatory approach. Biodivers. Conserv. 23, 3051-3071. http://dx.doi.org/10.1007/s10531-014-0763-x.

Levrel, H., Fontaine, B., Henry, P.Y. Jiguet, F, Julliard, R, Kerbiriou, C., Couvet, D., 2010. Balancing state and volunteer investment in biodiversity monitoring fo the implementation of CBD indicators: a French example. Ecol. Econ. 69, $1580-1586$.

Luescher, G., Schneider, M.K., Turnbull, L.A., Arndorfer, M., Bailey, D., Herzog, F, Pointereau, P., Richner, N., Jeanneret, P., 2014. Appropriate metrics to inform farmers about species diversity. Environ. Sci. Policy 41, 52-62.

Mac Nally, R., 2007. Consensus weightings of evidence for inferring breeding success in broad-scale bird studies. Austral Ecol. 32, 479-484. http://dx.doi.org/ 10.1111/j.1442-9993.2007.01714.x.

Martin, T.G., Burgman, M.A., Fidler, F., Kuhnert, P.M., Low-choy, S., Mcbride, M. Mengersen, K., 2011. Eliciting expert knowledge in conservation science. Conserv. Biol. 26, 29-38. http://dx.doi.org/10.1111/j.1523-1739.2011.01806.x.

McDonald-Madden, E., Baxter, P.W.J., Fuller, R.A., Martin, T.G., Game, E.T. Montambault, J., Possingham, H.P., 2011. Should we implement monitoring or research for conservation? Trends Ecol. Evol. 26, 108-109.

Miller, G.A., 1958. The magical number seven, plus or minus two: some limits on our capacity for processing information. Psychol. Rev. 63, 81-97.

Munda, G., 2004. Social multi-criteria evaluation: methodological foundations and operational consequences. Eur. J. Oper. Res. 158, 662-677. http://dx.doi.org 10.1016/S0377-2217(03)00369-2.

Noss, R.F., 1990. Indicators for monitoring biodiversity: a hierarchical approach Conserv. Biol. 4, 355-364.

Page, G., Bellotti, B., 2015. Farmers value on-farm ecosystem services as important but what are the impediments to participation in PES schemes? Sci. Total Environ. 515-516, 12-19. http://dx.doi.org/10.1016/j.scitotenv.2015.02.029.

Pe'er, G., Dicks, L.V., Visconti, P., Arlettaz, R., Báldi, A., Benton, T.G., Collins, S. Dieterich, M., Gregory, R.D., Hartig, F., Henle, K., Hobson, P.R., Kleijn, D. Neumann, R.K., Robijns, T., Schmidt, J. Shwartz, A. Sutherland, W. Turbé, A Wulf, F., Scott, A.V., 2014. EU agricultural reform fails on biodiversity. Science 344, 1090-1092.

Pereira, H.M., Ferrier, S., Walters, M., Geller, G.N., Jongman, R.H.G., Scholes, R.J., Bruford, M.W., Brummitt, N., Butchart, S.H.M., Cardoso, A.C., Coops, N.C. Dulloo, E., Faith, D.P., Freyhof, J., Gregory, R.D., Heip, C., Höft, R., Hurtt, G. etz, W., Karp, D.S., McGeoch, M.A., Obura, D., Onoda, Y., Pettorelli, N., Reyers, B. Sayre, R., Scharlemann, J.P.W., Stuart, S.N., Turak, E., Walpole, M., Wegmann, M. 2013. Essential biodiversity variables. Science 339, 277-278.

Pointereau, P., Langevin, B., 2012. Report on the Contribution of the Stakeholders to the Selection of the Biodiversity Indicators for Organic and Low Input Farming Systems. Deliverable 7.1. Available at: http://www.biobio-indicator.org/ deliverables/D71.pdf. Accessed on: March 2015.

Redpath, S.M., Arroyo, B.E., Leckie, F.M., Bacon, P., Bayfield, N., Gutierrez, R.J. Thirgood, S.J., 2004. Using decision modeling with stakeholders to reduce human - wildlife conflict: a raptor - grouse case study. Conserv. Biol. 18 350-359.

Reed, M.S., 2008. Stakeholder participation for environmental management: a literature review. Biol. Conserv. 141, 2417-2431. http://dx.doi.org/10.1016 j.biocon.2008.07.014.

R Development Core Team, 2012. R: a Language and Environment for Statistical Computing. R Foundation for Statistical Computing, Vienna, Austria. http://cran. r-project.org.

Rempel, R.S., Andison, D.W., Hannon, S.J., 2004. Guiding principles for developing an indicator and monitoring framework. For. Chron. 80, 82-90.

Rodrigues, A.S.L., Brooks, T.M., 2007. Shortcuts for biodiversity conservation planning: the effectiveness of surrogates. Annu. Rev. Ecol. Evol. Syst. 38, 713-737. http://dx.doi.org/10.1146/annurev.ecolsys.38.091206.095737.

Roy, B., Słowinski, R., 2013. Questions guiding the choice of a multicriteria decision aiding method. Eur. J. Decis. Process 1, 69-97. http://dx.doi.org/10.1007| s40070-013-0004-7.

Rutgers, M., van Wijnen, H.J., Schouten, A.J., Mulder, C., Kuiten, A.M.P., Brussaard, L Breure, a M., 2012. A method to assess ecosystem services developed from soil attributes with stakeholders and data of four arable farms. Sci. Total Environ. 415, 39-48. http://dx.doi.org/10.1016/j.scitotenv.2011.04.041.

Saaty, T.L., 2005. Theory and Applications of the Analytic Network Process: Decision Making with Benefits, Opportunities, Costs, and Risks. RWS Publications, Pittsburgh.

Schmeller, D.S., Henle, K. Loyau, A, Besnard, A., Henry, P., 2012. Bird-monitoring in Europe - a first overview of practices, motivations and aims. Nat. Conserv. 2 $41-57$.

Spangenberg, J.H., von Haaren, C., Settele, J., 2014. The ecosystem service cascade: further developing the metaphor. Integrating societal processes to accommodate social processes and planning, and the case of bioenergy. Ecol. Econ. 104, $22-32$. 
Sutherland, L.-A., 2011. "Effectively organic": environmental gains on conventional farms through the market? Land Use Policy 28, 815-824.

Swift, M.J., Izac, A.M.N., van Noordwijk, M., 2004. Biodiversity and ecosystem services in agricultural landscapes - are we asking the right questions? Agric Ecosyst. Environ. 104, 113-134.

Targetti, S., Herzog, F., Geijzendorffer, I.R., Wolfrum, S., Arndorfer, M., BalÃ, zs, K., Choisis, J.P., Dennis, P., Eiter, S., Fjellstad, W., Friedel, J.K., Jeanneret, P., Jongman, R.H.G., Kainz, M., Luescher, G., Moreno, G., Zanetti, T., Sarthou, J.P., Stoyanova, S., Bailey, D., Paoletti, M.G., Viaggi, D., 2014. Estimating the cost of different strategies for measuring farmland biodiversity: evidence from a Europe-wide field evaluation. Ecol. Indic. 45, 434-443. http://dx.doi.org/10. 1016/j.ecolind.2014.04.050.

Targetti, S., Viaggi, D., Cuming, D., Sarthou, J.-P., Choisis, J.P., 2012. Assessing the costs of measuring biodiversity: methodological and empirical issues. Food Econ. 9, 2-9. http://dx.doi.org/10.1080/16507541.2012.695118.

Theobald, E.J., Ettinger, A.K., Burgess, H.K., DeBey, L.B., Schmidt, N.R., Froehlich, H.E Wagner, C., HilleRisLambers, J., Tewksbury, J., Harsch, M.A., Parrish, J.K., 2015. Global change and local solutions: tapping the unrealized potential of citizen science for biodiversity research. Biol. Conserv. 181, 236-244. http://dx.doi.org 10.1016/j.biocon.2014.10.021.

Tilman, D., Fargione, J., Wolff, B., Antonio, C.D., Dobson, A., Howarth, R. Schindler, D., Schlesinger, W.H., Simberloff, D., Swackhamer, D., 2001. Forecasting agriculturally driven global environmental change. Science 292, $281-285$.

Tittensor, D.P., Walpole, M., Hill, S.L.L., Boyce, D.G., Britten, G.L., Burgess, N.D. Butchart, S.H.M., Leadley, P.W., Regan, E.C., Alkemade, R., Baumung, R. Bellard, C., Bouwman, L., Bowles-Newark, N., Chenery, A.M., Cheung, W.W.L., Christensen, V., Cooper, H.D., Crowther, A.R., Dixon, M.J.R., Galli, A., Gaveau, V., Gregory, R.D., Gutierrez, N.L., Hirsch, T.L., Hoft, R., Januchowski-Hartley, S.R. Karmann, M., Krug, C.B., Leverington, F.J., Loh, J., Kutsch Lojenga, R., Malsch, K. Marques, A., Morgan, D.H.W., Mumby, P.J., Newbold, T., Noonan-Mooney, K. Pagad, S.N., Parks, B.C., Pereira, H.M., Robertson, T., Rondinini, C., Santini, L.,
Scharlemann, J.P.W., Schindler, S., Sumaila, U.R., Teh, L.S.L., van Kolck, J., Visconti, P., Ye, Y., 2014. A mid-term analysis of progress towards international biodiversity targets. Science 346, 241-244.

Turnhout, E., Hisschemöller, M., Eijsackers, H., 2007. Ecological indicators: between the two fires of science and policy. Ecol. Indic. 7, 215-228.

Vanclay, F., 2004. Social principles for agricultural extension to assist in the promotion of natural resource management. Aust. J. Exp. Agric. 44, 213-222.

Wallenius, J., Dyer, J.S., Fishburn, P.C., Steuer, R.E., Zionts, S., Deb, K., 2008. Multiple criteria decision making, multiattribute utility theory: recent accomplishments and what lies ahead. Manage. Sci. 54, 1336-1349. http://dx.doi.org/10.1287/ mnsc.1070.0838.

Walpole, M., Almond, R.E.A., Besançon, C., Butchart, S.H.M., Campbell-Lendrum, D., Carr, G.M. Collen, B. Collette, L, Davidson, N.C. Dulloo, E. Fazel, A.M. Galloway, J.N., Gill, M., Goverse, T., Hockings, M., Leaman, D.J., Morgan, D.H.W., Revenga, C., Rickwood, C.J., Schutyser, F., Simons, S., Stattersfield, A.J., Tyrrell, T.D., Vié, J.-C., Zimsky, M., 2009. Tracking progress toward the 2010 biodiversity target and beyond. Science 325, 1503-1504.

White, B., 2005. An economic analysis of ecological monitoring. Ecol. Modell. 189, 241-250. http://dx.doi.org/10.1016/j.ecolmodel.2005.03.010.

White, B., Sadler, R., 2012. Optimal conservation investment for a biodiversity-rich agricultural landscape. Aust. J. Agric. Resour. Econ. 56, 1-21.

Wossink, A., Swinton, S.M., 2007. Jointness in production and farmers' willingness to supply non-marketed ecosystem services. Ecol. Econ. 64, 297-304.

Zabel, A., Roe, B., 2009. Optimal design of pro-conservation incentives. Ecol. Econ. 69, 126-134. http://dx.doi.org/10.1016/j.ecolecon.2009.08.001.

Zavalloni, M., Raggi, M., Targetti, S., Viaggi, D., 2015. Agricultural policies and the emergence of voluntary landscape enhancement efforts: an exploratory analysis of rural tourism using an agent based model. J. Environ. Plann. Manage 58 (12), 2159-2175.

Zhang, W., Ricketts, T.H., Kremen, C., Carney, K., Swinton, S.M., 2007. Ecosystem services and dis-services to agriculture. Ecol. Econ. 64, 253-260. 